\title{
PURWARUPA SISTEM PEMANTAUAN KUALITAS UDARA DAN CUACA MELALUI WEB BERBASIS WIRELESS SENSOR NETWORK
}

\author{
Ahmad Sabiq ${ }^{1}$, Nurmaya ${ }^{2}$, Topan Alfarisi ${ }^{3}$, Yusran Ade Pratama ${ }^{4}$ \\ 1,2,3,4Teknik Informatika,Universitas YARSI \\ Jakarta,Indonesia \\ e-mail:1ahmad.sabiq@yarsi.ac.id, ${ }^{2}$ urmaya@yarsi.ac.id, ${ }^{3}$ topan.alfa@gmail.com, \\ 4yusran.ade@premiumfast.net
}

\begin{abstract}
Abstrak
Kebutuhan informasi kualitas udara menjadi salah satu hal yang dibutuhkan untuk keperluan aktifitas, khususnya di daerah perkotaan yang memiliki mobilitas tinggi.Pengukuran kualitas udara yang dilakukan pada umumnya hanya dilakukan pada satu titik untuk satu kota.Dengan menggunakan teknoogi Wireless Sensor Network (WSN),pemantauan kondisi udara dancuacadi beberapa titik dalam suatu wilayah dapat dilakukan. Pada penelitian ini, dikembangkan purwarupa sistem pemantauan kualitas udara dan cuaca berbasis WSN pada platform Arduino pada dan Raspberry Pi yang dapat diakses melalui web. Setiap node terhubung melalui jaringan mesh berbasis ZigBee menggunakan modul XBee Series-2. Dari hasil pengujian didapatkan sistem WSN yang dirancang dapat mengaukuisisi data udara seperti suhu, kelembapan, kadar $\mathrm{CO}$ dan $\mathrm{CO}_{2}$, dankondisihujan. Data yang berhasil diakusisi kemudian disimpan ke dalam database pada server, sehingga informasi kualitas udara dan cuaca tersebut dapat ditampilkan di laman web pada perangkat yang terhubung ke server melalui internet.
\end{abstract}

Katakunci:WSN, web, Kualitas Udara.

\begin{abstract}
The air quality information becomes one of the needed information for doing activities especially in the urban area that has a high mobility. The quality weather measurement has done mostly at one point for one city. Using Wireless Sensor Network (WSN), the monitoring of air and weather condition in a few points area could been done. This research aims to develop the web-based monitoring system of air and weather quality based on WSN on Arduino Platform and Raspberry pi. Each node is connected to mesh based on ZigBee using the Xbee Series-2. The result shows the system can obtain the air data such as weather, humidity, $\mathrm{CO}$ and $\mathrm{CO} 2$ degree includes the light intensity and the rain condition. Then, The data is stored on the database server. Hence, the quality of air and weather information can be present on the web connected to the server via the the internet.
\end{abstract}

Keywords: WSN, web, Air Quality.

\section{PENDAHULUAN}

Dalam kehidupan sehari-hari, manusia tidak bisa lepas dari udara, udara menjadi salah satu kebutuhan utama makhuk hidup untuk mendapatkan oksigen melalui pernafasan. Udara merupakan campuran gas yang terdapat pada permukaan bumi, gas nitrogen $78,1 \%$, oksigen $20,93 \%$, dan karbondioksida $\quad 0,03 \%$, sementara selebihnya berupa gas argon, neon, kripton, xenon dan helium. Udara juga mengandung uap air, debu, bakteri, spora dan sisa tumbuh-tumbuhan (Candra B. 2006).

Daerah urban atau perkotaan merupakan daerah yang memiliki tingkat pencemaran udara lebih tinggi dari daerah pedesaan, masyarakat perkotaan sendiri memiliki tingkat mobilitas yang tinggi, sehingga kebutuhan akan informasi cuaca dan udara menjadi suatu hal yang dapat digunakan untuk keperluan aktifitas di daerah perkotaan.Kementrian Lingkungan Hidup dan Kehutanan (KLHK) 
memilikisistempengukurankualitasudara di beberapakota(Kementrian Lingkungan Hidup dan Kehutanan, 2016), namun pengukuran yang dilakukan oleh KLHK hanya pada satu titik untuk satu kota, sehingga hal ini tidak bisa menjadi acuan kualitas udara untuk seluruh lokasi yang ada.

\section{Dalamsatu}

dekadeini,telahmulaidikembangkanteknologi bernamaWireless Sensor Network(WSN) atau jaringan sensor nirkabel seperti yang ada pada gambar 1, padateknologiiniterdapatbeberapa sensor yang dapatmengirimkan data kesebuahtujuan yang disebutsinksecaramulti-hopmelaluijaringan ad-hoc(Rawat, P., Singh, K. D., Chaouchi, H., \& Bonnin, J. M., 2014). Keuntungandaripenggunaan WSN adalahkebutuhan peralatan yang relatifmurah namun dapat memberikan informasi dari lingkungan, seperti suhu, tekananudara ataupunpencemaran udara dengan konsumsi daya yang
rendah(Boubrima, A., Bechkit, W., Rivano, H., \& Ruas, A., 2016) (Jaladi, A. R., Khithani, K., Pawar, P., Malvi, K., \& Sahoo, G., 2017). Dengan menggunakan WSN, kondisi dan kualitas udara atau tingkat polusi udara berupa kandungan gas karbon monoksida (CO) dan Liquid Petroleum Gas (LPG) dapat dibaca menggunakan sensor dan kemudian dikirimkan kepada sink untuk kemudian diolah menjadi informasi (AlHaija, Q. A., Al-Qadeeb, H., \& Al-Lwaimi, A., 2013). Sebuah open-source electronic platform, yaitu perangkat Arduino dapat digunakan dalam merancang node sensor pada WSN. Data yang didapatkan dari sensor secara real time dimasukkan ke dalam sebuah database serveryang ada di perangkat Raspberry $\mathrm{Pi}$ melalui jaringan. Perangkat Raspberry $\mathrm{Pi}$ yang digunakan berfungsi juga sebagai web server, sehingga data tersebut dapat diakses secara real time melalui laman web (Boubrima, A., Bechkit, W., Rivano, H., \& Ruas, A., 2016) (Sabiq, A., Nurmaya, \&Alfirisi T., Juli 2017).

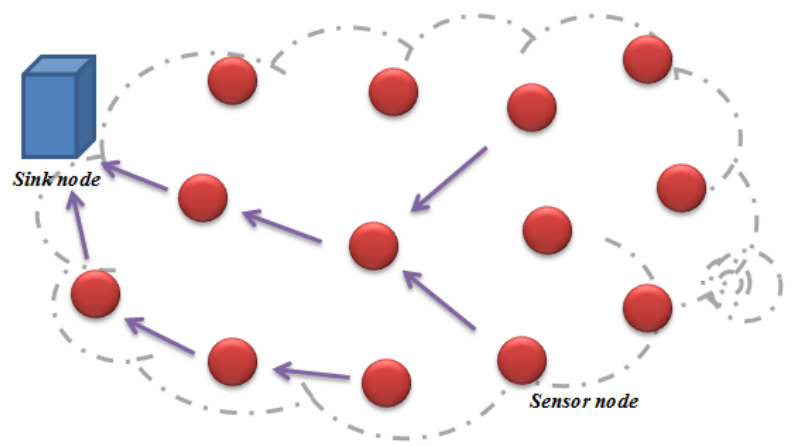

Gambar 1.Sistem Wireless Sensor Network

Untuk mentransmisikan data hasil pembacaan sensor dari sensor node ke sink node, koneksi melalui Bluetooth dapat digunakan untuk mengimplemetasikan jaringan ad-hoc multi-hop pada sistem WSN (Kasar, A. R., Khemnar, D. S., \& Tembhurnikar, N. P., 2013). Perangkat berbasis ZigBee seperti XBee juga dapat digunakan untuk mengimplementasikan jaringan ad-hoc multi-hop pada WSN (Kulkarni, D., Shaikh, S., Shirsath, A., \&Kadam, T., 2015). ZigBee merupakan jaringan mesh nirkabel yang bertenaga dan berdaya rendah. Protokol ZigBee dibangun di atas standard IEEE 802.15.4 (ZigbeeAlliance,2017)(IEEE, 2017). Perangkat dengan protokol ZigBee yang berstandard 802.15.4 saat ini tersedia di pasaran yang digunakan untuk membuat purwarupa sistem nirkabel, seperti seri modul XBee dari Digi yang menerapkan standard IEEE 802.15.4 dan protokol jaringan ZigBee (Digi, 2017).

Pada penelitian ini dikembangkan sebuah purwarupa sistem untuk memantau kualitas udara berbasis Wireless Sensor Network (WSN) menggunakan Arduino dan Raspberry Pi melalui jaringan ZigBee, yang 
dapat diakses melalui jaringan internet. Sehingga data kondisi kualitas udara, seperti suhu, kelembapan, kadar CO dan $\mathrm{CO} 2$, serta kondisi hujan atau tidaknya di lingkungan tersebut dapat tersimpan dan dapat dipantau dari halaman web melalui perangkat-perangkat yang terhubung ke server melalui jaringan internet.

\section{METODE}

\section{Rancangan Sistem}

Pada penelitian ini dirancang sistem pemantauan yang terdiri dari beberapa perangkat sensor node yang dapat mengirimkan pesan berupa data yang dibaca dari sensor yang terpasang melalui jaringan nirkabel berbasis ZigBee ke node pusat atau sink. Setiap perangkat sensor nodeharus dapat meneruskan paket data dari perangkat lain ke sink. Data yang diterima oleh sink kemudian dikirim ke dalam database pada server. Pada server data diolah untuk menjadi informasi yang dapat ditampilkan dan dapat diakses dari laman web melalui jaringan internet yang diilustrasikan pada gambar 2 ..

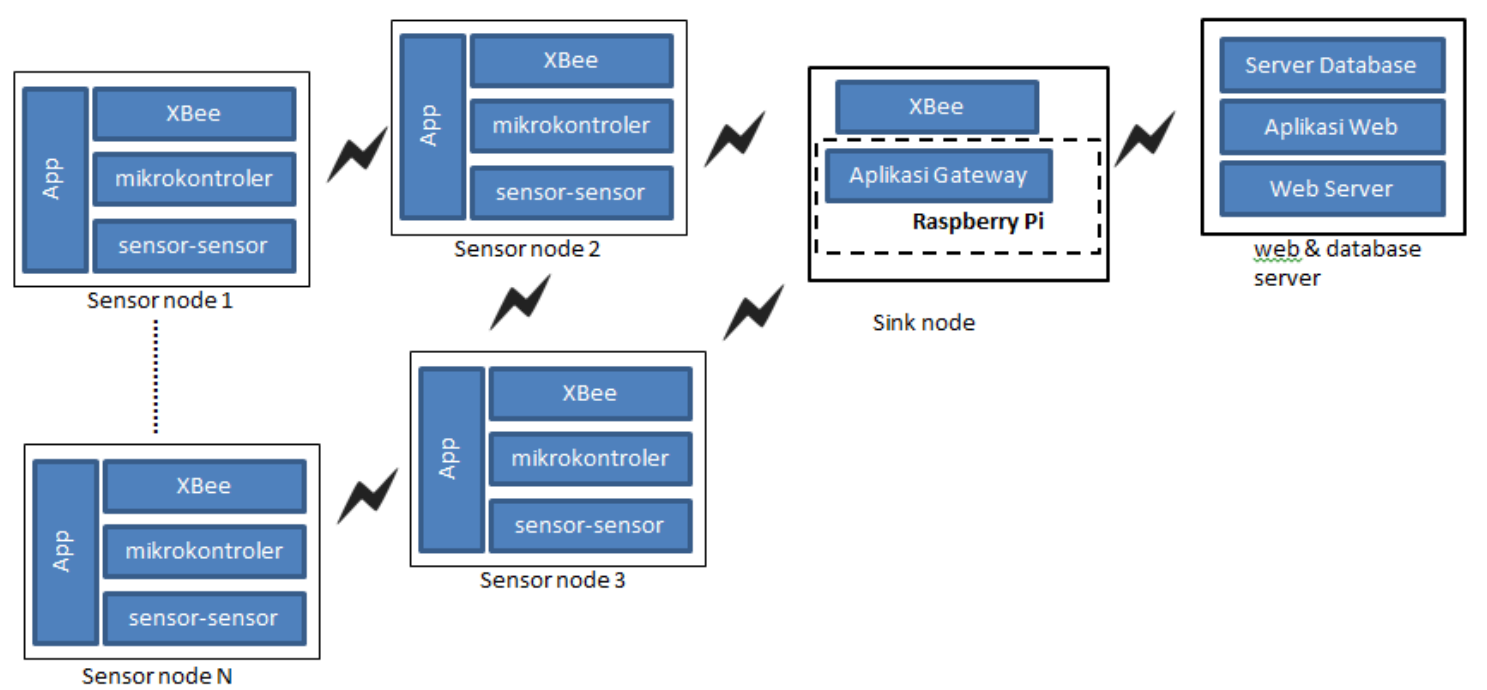

Gambar 2.Desain Rancangan Sistem

\section{Perancangan Sensor Node}

Sensor node pada sistem ini dirancang untuk dapat membaca data suhu, kelembapan, kualitas udara, gas CO, intensitas cahaya dan kondisi hujan atau tidak. Pada rancangan sensor nodeyang ditunjukan pada gambar 3 digunakan perangkat Mikrokontroller Arduino, sensor DHT22 (Suhu \& Kelembapan), sensor MQ135(Udara), MQ-7(Gas CO), sensor raindrop (hujan/air), serta modul Xbee sebagai pengirim data secara nirkabel.
Pada perangkat mikrokontroller Arduino dirancang sebuah program yang berjalan seperti pada diagram alir yang ditunjukan pada gambar 4. Besaran fisis akan dibaca oleh sensor-sensor yang dipasang pada sensor node. Setelah data dari semua sensor didapatkan, data tersebut dikirimkan ke sink node melalui jaringan ZigBee menggunakan modul XBee yang terpasang. 


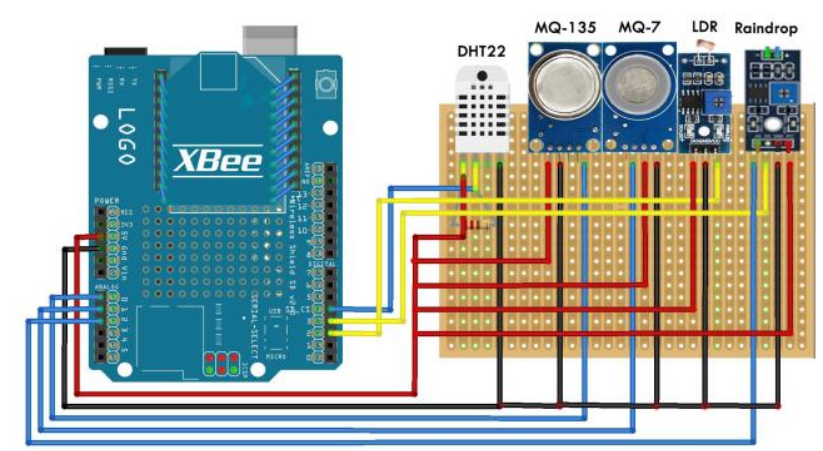

Gambar3.Desain Rancangan Sistem

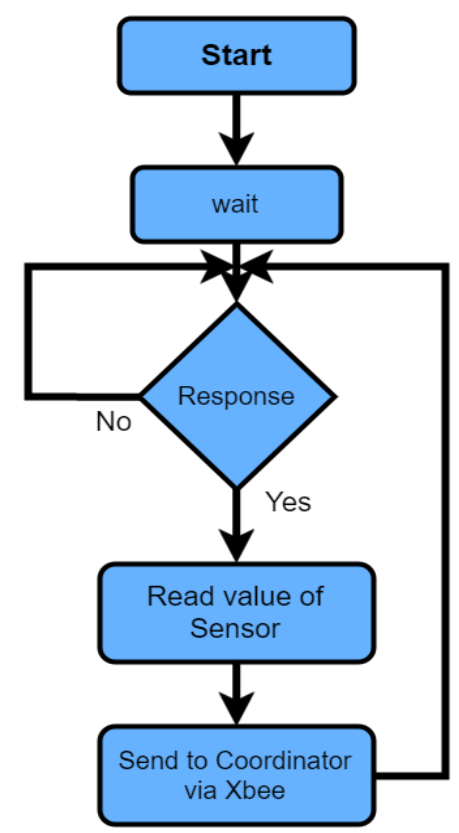

Gambar 4.Desain Rancangan Sistem

\section{Perancangan Sink Node}

Pada sink node digunakan sebuah perangkat komputer berupa single board Raspberry Pi 3 Model B untuk menerima data yang dikirim dari sensor node. Raspberry Pi 3 Model B memiliki spesifikasi CPU tipe ARMv8 dengan kecepatan $1.2 \mathrm{GHz}$ 64-bit quad-core dan memori LPDDR2 SDRAM 1GB. Untuk dapat menerima data yang dikirim dari sensor nodemelalui jaringan ZigBee, ditambahkan modul Xbee Series-2 yang dihubungkan ke Raspberry Pi melalui pin GPIO seperti yang ditunjukan pada gambar 5 .
Pada diagram fungsional yang ada pada gambar 6 , sink nodeyang dirancang terdiri dari aplikasi gateway yang ada pada Raspberry $\mathrm{Pi}$ yang terhubung dengan modul XBee dan perangkat Wifi. Data yang diterima oleh modul XBee dibaca oleh aplikasi gateway yang dibangun mengunakan Procesing di atas sistem operasi Ubuntu Mate, serta library BezierSQL untuk mengkoneksikan dan meneruskan data dari ke database servermelalui koneksi internet. 


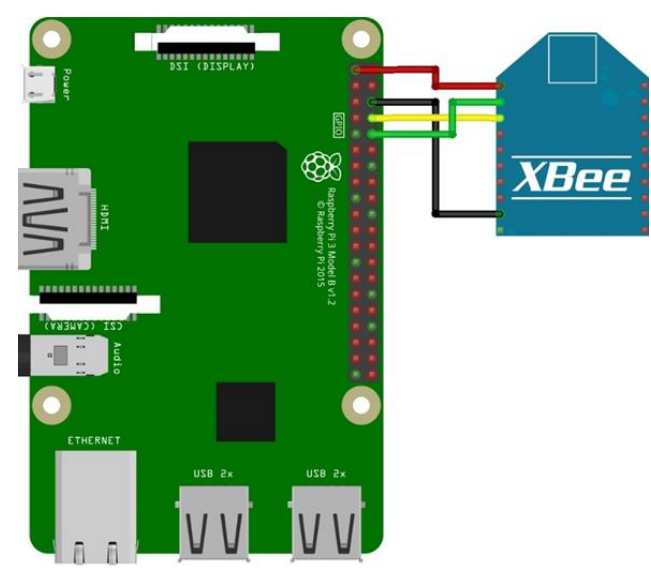

Gambar 5.Desain rancangan sink node

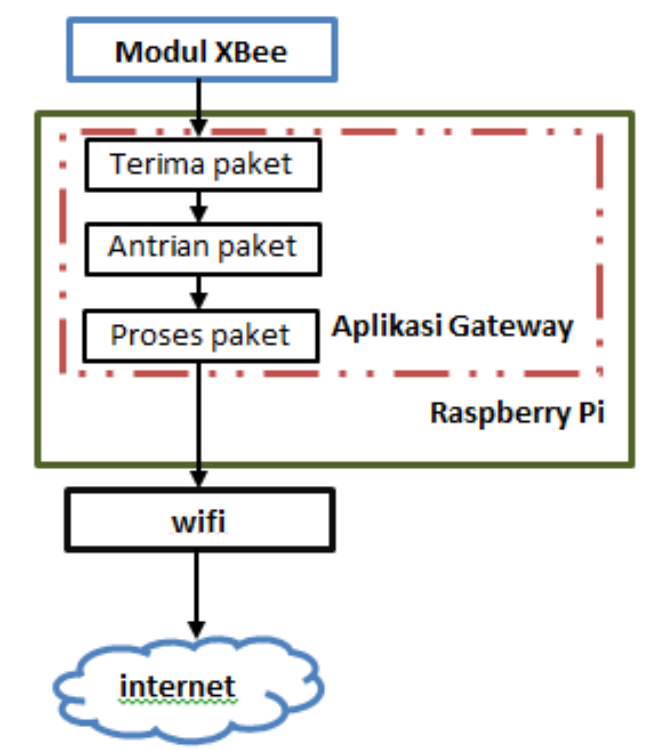

Gambar 6.Diagram fungsional sink node

Aplikasi gateway yang dibuat pada sink nodedirancang dengan alur seperti pada gambar 7. Setelah melakukan inisialisasi awal, dilakukan pengecekan secara berulang apakah ada data yang diterima dari modul XBee, jika data diterima dilakan pembacaan node pengirim dari data tersebut. Setelah diketahui node pengirim, data dipisahkan antara data nomorataunamanode, lokasinode, suhu, kelembapan, CO, MPdankondisihujan. Setelah data dari semua sensor di setiap node dipisahkan, berikutnya data dikirimkedatabase servenuntukdisimpan ke dalam tabel database. 


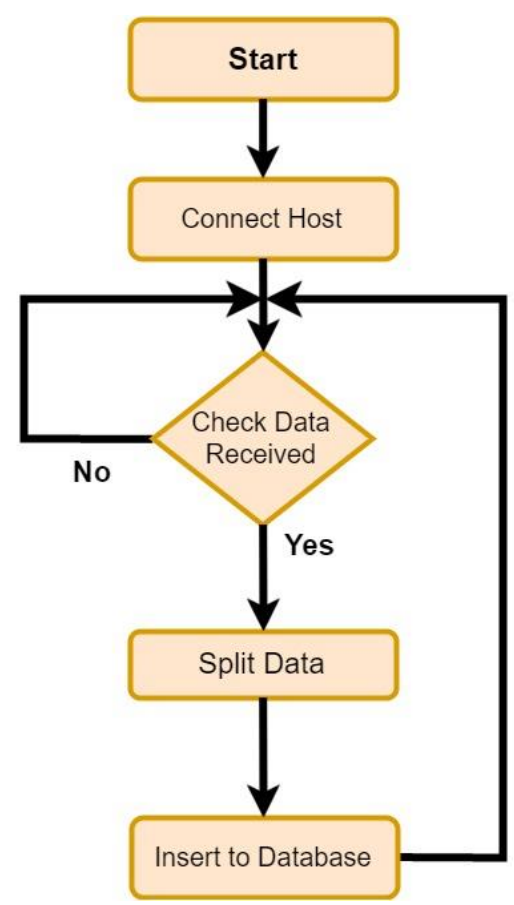

Gambar 7.Diagramalir aplikasi gateway pada sink node.

\section{Perancangan Server}

Pada Server digunakan mesin server virtual yang yang digunakan database serverdanweb server dengan spesifikasi :

- Processor 1 CPU core (Dual Intel Xeon hypervisors)

- RAM 1024MB

- SSD $25 \mathrm{~GB}$

- Sistem Operasi Centos 7.
Kernel yang digunakan pada sistem operasi Centos 7 adalah seri 3.10.0327.el7.x86_64. Untuk menyimpan database yang dikirim dari sink digunakan database engine Mariadb-server, sedangkan pada web server digunakan NginX.

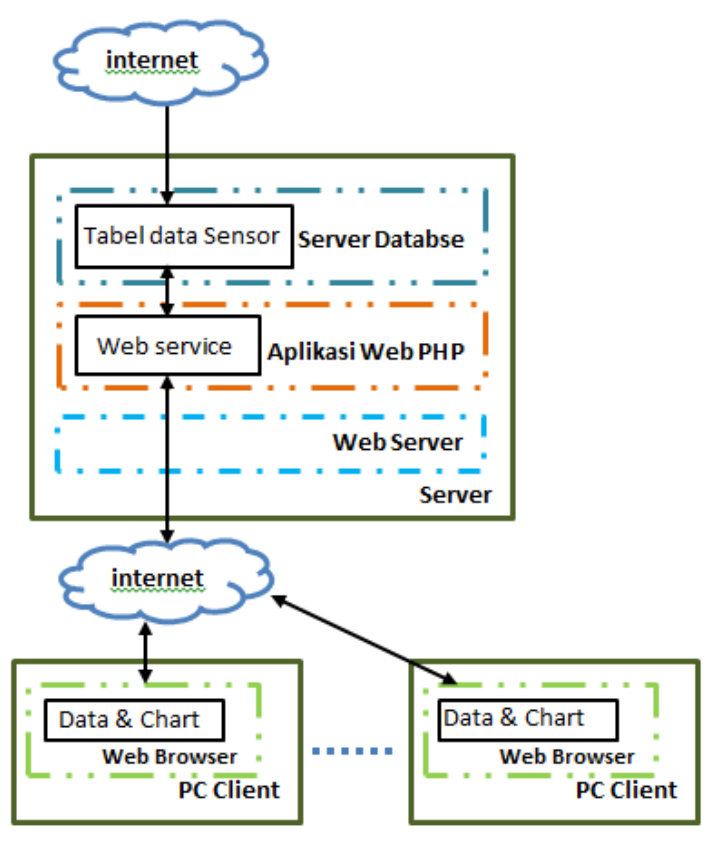

Gambar8.Diagramfungsionalserver 


\section{HASILDANPEMBAHASAN}

Sensor node yang telah dirancang diimplementasikan seperti pada gambar 8.Modul Arduino UNO dihubungkan dengan sensor DHT22 untuk membaca nilai suhu \& kelembapan, sensor MQ-135 untuk membaca nilai kualitas udara, sensor MQ-7 untuk membaca kadar gas CO di udara, sensor hujan untuk mendeteksi adanya tetesan air hujan, serta modul Xbee Series2 untuk menghubungkan sensor nodeke jaringan.Digunakan Arduino IDE untuk membuat program padasensor nodesesuai dengan diagram alir pada gambar 4 yang ditanam pada Arduino UNO. Sumber tegangan dari sensor nodemenggunakan Aki $12 \mathrm{~V}$ yang telah disesuaikan keluarannya dengan rangkaian regulator tegangan. Sedangkan sink nodeuntuk menerima data dari sensornode diimplementasikan dengan perangkat Raspberry $\mathrm{Pi}$ yang dihubungkan dengan modul XBee Series-2, serta dibuatkan aplikasi gateway yang dapat menerima data dari sensornodeyang dikirim ke sink node melalui perangkat XBee, data yang dibaca tersebut kemudian disimpan dalam database menggunakan Processing sesuai dengan alur pada gambar 7 .

Purwarupa sistem diuji dengan memasang sink node dan sensor nodedi sekitar kampus Universitas YARSI Jakarta Pusat. Gambar 9 menunjukan sebaran 3 buah sensor nodedi tempat-tempat yang banyak dilewati para pejalan kaki dan pengendara serta dapat menjangkau sink node baik secara langsung maupun melalui sensor nodelainnya secara multi-hop.

Jarak sensor nodeterdekat dengan sink node adalah $30 \mathrm{~m}$, node tersebut berguna juga untuk meneruskan data dari sensor nodeyang jaraknya jauh dan tidak terjangkau dari sink node. Jarak antara sensor node1 dengan sink adalah 44 meter, jarak antara node 2 dengan node 3 serta antara node 3 dengan sink nodeadalah 30 meter. Jarak maksimal yang dapat dijangkau untuk berkomunikasi dengan node terdekatnya adalah 45 meter. Setiap sensornodediatur untuk mengirimkan data lokasi,nama jalan, longtitude, suhu, kelembapan, cahaya, gas $\mathrm{CO}$, gas $\mathrm{CO} 2$, hujan dengan rentang waktu pengiriman 30 detik.

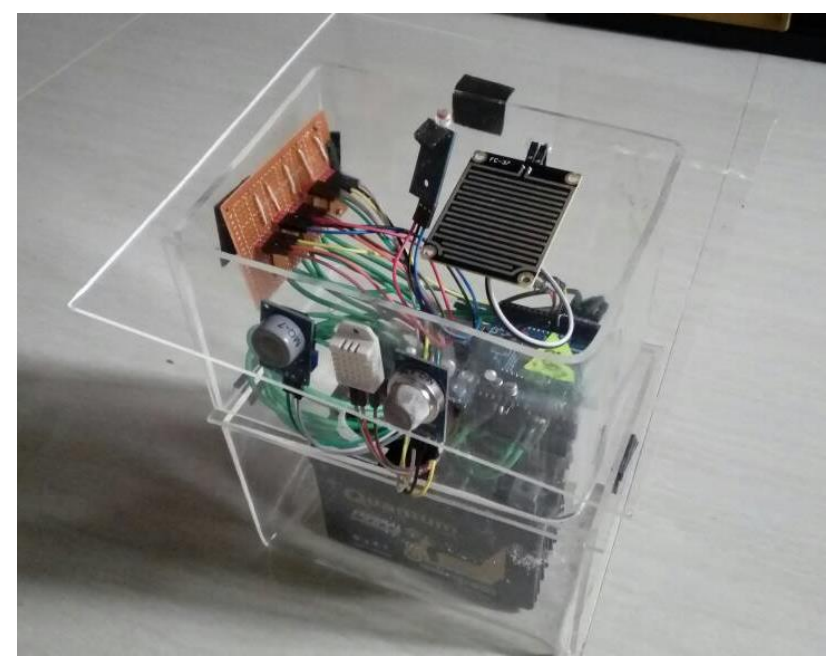

Gambar 8.sensornodedan sink node 


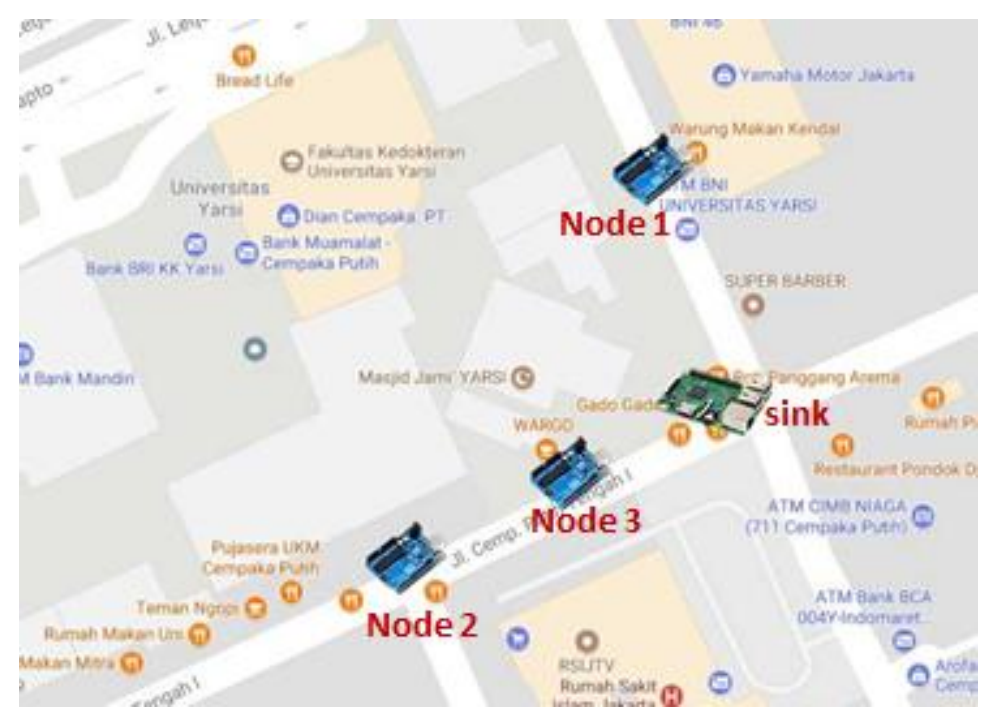

Gambar 9.Sebaran wireless sensor network

Data hasil pembacaan sensor dari sensornodepada hasil pengujian dapat tersimpan pada database dan dapat ditampilkan melalui aplikasi web seperti yang ditunjukan pada gambar 10. Informasi kualitas udara dan cuaca tersebut dapat diakses melalui perangkat yang terhubung melalui jaringan internet. Pada aplikasi web tersebut dapat ditampilkan data terbaru dari suhu, kelembapan, kadar $\mathrm{CO}, \mathrm{CO} 2$ serta kondisi hujan yang didapatkan dari sensor node dalam bentuk tabel. Data dari masing- masing node juga dapat ditampilkan dalam bentuk grafik seperti pada gambar 11 yang dapat memberikan salah satu informasi perubahan suhu, kelembapan, kadar $\mathrm{CO}$, CO2 atau kondisi hujan selama beberapa jam terakhir dalam satu titik yang mewakili satu sensornode.

Dengan memanfaatkan GIS (geographic information system) Api dari Google,lokasi sensornodejuga dapat diketahui melalui peta yang ditampilkan pada laman web seperti pada gambar 12 .

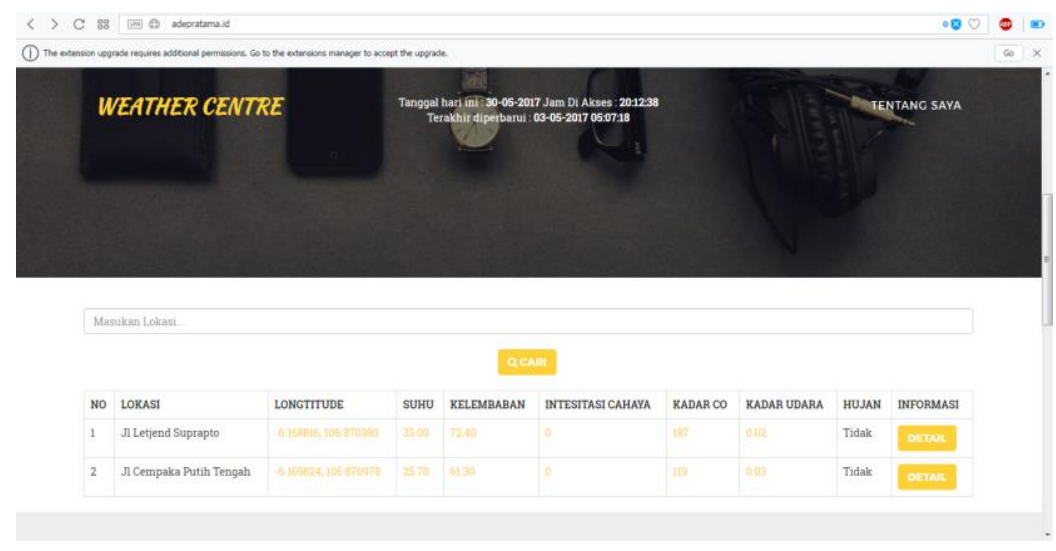

Gambar 10.Tampilan antarmuka halaman web. 


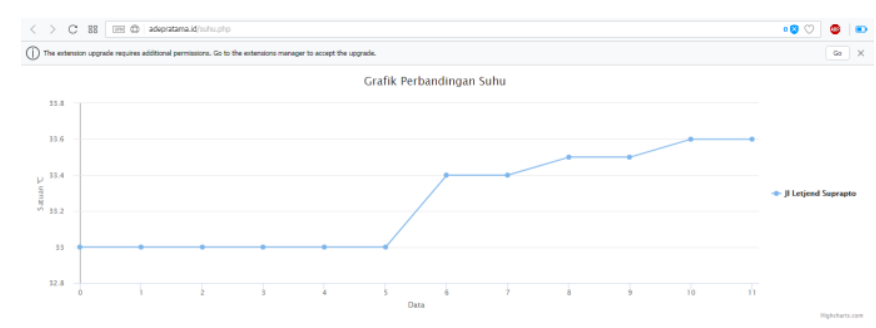

Gambar 11.Tampilan data suhu pada laman web dalam bentuk grafik

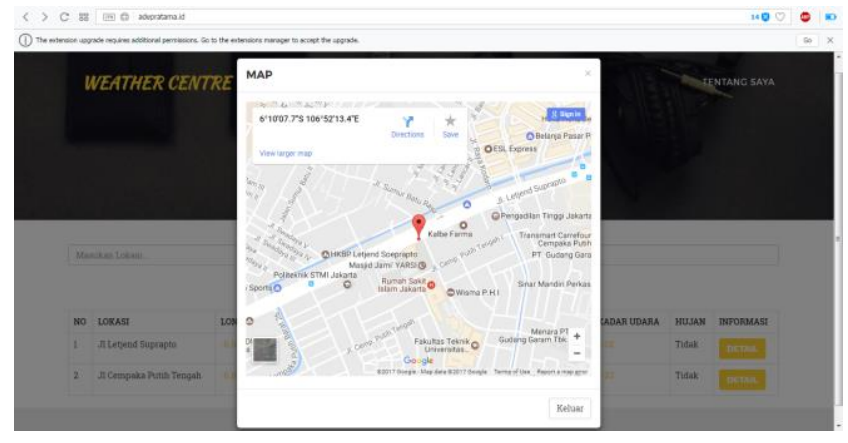

Gambar 12.Tampilan detail lokasi sensornodepada laman web.

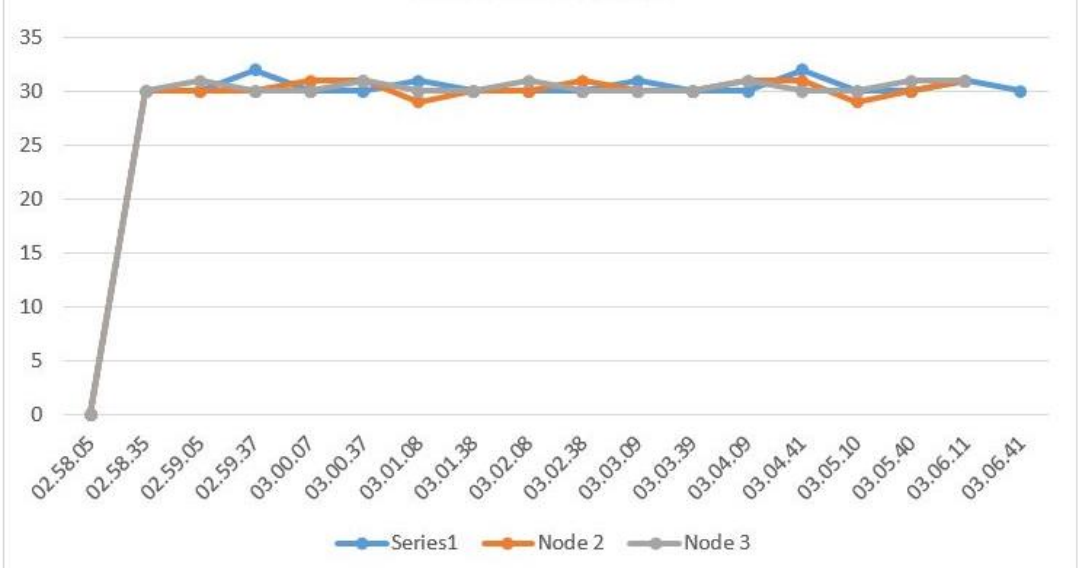

Gambar 13. Grafik perbandingan waktu pengiriman data ketigasensornode.

Dari hasil pengukuran jeda waktu diterimanya data hasil pengiriman, didapatkan grafik perbandingan jeda waktu diterimanya data di sink node dari setiap sensor node pada gambar 13 yang dihasilkan selama pengujian yang berlangsung selama 10 menit.

Setiap sensor node yang dipasang, diprogram untuk mengirimkan data sensor setiap 3 detik ke sink node. Pada node 1 yang terhubung langsung ke sink node dengan jarak 44 meter, didapatkandelay penerimaan data pada sink node maksimal 2 detik. Sedangkan pada node 3 yang terhubung langsung ke sink node dengan jarak 30 meter serta node 2 yang terhubung melalui node 3 mempunyai delay penerimaan data pada sink node maksimal 1 detik.

Semua data sensor yang dikirimkan ke sink node secara keseluruhan dapat diteruskan dan direkam pada tabel database yang ada di server serta dapat ditampilkan pada laman web melalui Jurnal Sains dan Teknologi| 256 
koneksi internet baik dalam format tabel maupun grafik secara realtime. Purwarupa yang telah dihasilkan dari penelitian ini diharapkan dapat dikembangkan lebih lanjut menjadi sistem yang dapat digunakan oleh masyarakat urban perkotaan untuk memantau kualitas udara dan kondisi cuaca di beberapa tempat secara realtime, khususnya pada tempat-tempat yang akan dikunjungi melalui perangkat-perangkat yang dapat terhubung dengan internet.

\section{SIMPULAN}

Purwarupa sistem pemantauan kualitas udara dan cuaca berbasis WSN telah dikembangkan menggunakan Arduino pada sensor node dan Raspberry Pi pada sink node. Sensornodeyang dibangun di atas platform Arduino berhasil menangkap data suhu, kelembapan, kadar CO dan $\mathrm{CO} 2$ serta kondisi hujan. Data dari masingmasing sensor node dikirimkan ke sink node melalui jaringan berbasis ZigBee menggunakan modul XBee Series-2. Data yang dikumpulkan oleh sink dari sensor diteruskan kedalam database serveryang ada pada serverdan diolah menjadi sebuah informasi yang dapat ditampilkan di laman web pada perangkat yang terhubung ke server melalui internet.

\section{DAFTAR PUSTAKA}

Al-Haija, Q. A., Al-Qadeeb, H., \& Al-Lwaimi, A. (2013). Case Study: Monitoring of AIR quality in King Faisal University using a microcontroller and WSN. Procedia Computer Science, 21, 517521.

Boubrima, A., Bechkit, W., Rivano, H., \& Ruas, A. (2016, May). Wireless Sensor Networks Deployment for Air Pollution Monitoring. In TAP 2016-21st International Transport and Air Pollution Conference.

Chandra,

B. 2006.PengantarKesehatanLingkungan Jakarta: PenerbitBukuKedokteran EGC.

Digi, 2017. Digi XBee/RF Solution, 802.15.4, https://www.digi.com/products/xbee-rfsolutions.
IEEE, 2017. 802.15 WPAN Task Group 4 (TG4), http://www.ieee802.org/15/pub/TG4.ht $\mathrm{ml}$

Jaladi, A. R., Khithani, K., Pawar, P., Malvi, K., \& Sahoo, G. (2017). Environmental Monitoring Using Wireless Sensor Networks (WSN) based on IOT. International Research Journal of Engineering Technology (IRJET), vol. 04, no. 1, pp. 1371-1378.

Kasar, A. R., Khemnar, D. S., \& Tembhurnikar, N. P. (2013). WSN based air pollution monitoring system. International Journal of Science and Engineering Applications, 2(4), 55-59.

Kementrian Lingkungan Hidup dan Kehutanan. 2016. Indeks Standard Pencemaran Udara (ISPU) Propinsi DKI Jakarta. http://iku.menlhk.go.id/index/index/kab kota/3173/prop/31/id/ID-JK. Diskses tanggal 25 April 2016.

Kulkarni, D., Shaikh, S., Shirsath, A., \&Kadam, T., (2015) "Traffic and Weather Monitoring System Using Wireless Sensor Networks", International Journal of Advanced Research in Computer and Communication Engineering, vol. 4, no. 3, pp. 631-634.

Rawat, P., Singh, K. D., Chaouchi, H., \& Bonnin, J. M. (2014). Wireless sensor networks: a survey on recent developments and potential synergies. The Journal of supercomputing, 68(1), 1-48.

Sabiq, A., Nurmaya, \&Alfirisi T., (Juli 2017).Sistem Wireless Sensor Network Berbasis Arduino Uno dan Raspberry untukPemantauanKualitasUdara di CempakaPutihTimur, Jakarta Pusat.pada The $9^{\text {th }}$ National Conference on Information Technology and Electrical Engineering. pp. 301-305.

ZigBee Alliance, 2017. Zigbee: The Open, Global Wireless Standard for Connecting Everyday Devices. http://www.zigbee.org/zigbee-fordevelopers/. 